\title{
Pseudoalteromonas donghaensis sp. nov., isolated from seawater
}

Correspondence

Dong-Hyun Roh

dhroh@chungbuk.ac.kr

\author{
Yong-Sik Oh, ${ }^{1}$ A-Rum Park, ${ }^{1}$ Je-Kwan Lee, ${ }^{1}$ Chae-Sung Lim, ${ }^{1}$ \\ Jae-Soo Yoo ${ }^{2}$ and Dong-Hyun Roh ${ }^{1}$
}
${ }^{1}$ Department of Microbiology and Biotechnology Research Institute, Chungbuk National University, Cheongju 361-763, Chungbuk, Republic of Korea
${ }^{2}$ School of Electrical and Computer Engineering, Chungbuk National University, Cheongju 361- 763, Chungbuk, Republic of Korea

\begin{abstract}
A Gram-negative, rod-shaped, motile and aerobic bacterium, designated strain $\mathrm{HJ}_{51}{ }^{\top}$, was isolated from a seawater sample from the East Sea, near South Korea. The isolate grew slowly at $4{ }^{\circ} \mathrm{C}$, was able to grow at $40{ }^{\circ} \mathrm{C}$, required $\mathrm{NaCl}$ and grew optimally at $\mathrm{pH}$ 6.5-7.0. The $\mathrm{G}+\mathrm{C}$ content of the genomic DNA was $41.8 \mathrm{~mol} \%$. The major fatty acids were summed feature 4 $\left(\mathrm{C}_{16: 1} \omega 7 c\right.$ and/or iso- $\left.\mathrm{C}_{15: 0} 2-\mathrm{OH}\right), \mathrm{C}_{16: 0}$ and summed feature $7\left(\mathrm{C}_{18: 1} \omega 7 c, \mathrm{C}_{18: 1} \omega 9\right.$ t and/or $\left.\mathrm{C}_{18: 1} \omega 12 t\right)$. Phylogenetic analysis based on 16S rRNA gene sequences revealed that strain HJ51 ${ }^{\top}$ belonged to the genus Pseudoalteromonas and had 91.7-98.9\% 16S rRNA gene sequence similarity with type strains of species of the genus Pseudoalteromonas. Strain HJ51 ${ }^{\top}$ had 7.2 \% DNA-DNA relatedness with Pseudoalteromonas mariniglutinosa DSM $15203^{\top}$ and $12.9 \%$ with Pseudoalteromonas prydzensis DSM $14232^{\top}$. On the basis of the phenotypic, phylogenetic and genomic data, strain $\mathrm{HJ}_{51}{ }^{\top}$ represents a novel species of the genus Pseudoalteromonas, for which the name Pseudoalteromonas donghaensis sp. nov. is proposed. The type strain is $\mathrm{HJ}_{51}^{\top}$ (=KCTC $\left.22219^{\top}=\mathrm{LMG} 24469^{\top}\right)$.
\end{abstract}

The genus Pseudoalteromonas was separated from the genus Alteromonas, which was originally described by Baumann et al. (1972), on the basis of comparative 16S rRNA gene sequence analysis (Gauthier et al., 1995). Many members of the genus Pseudoalteromonas have been isolated from marine environments and the genus is one of largest within the class Gammaproteobacteria. The abundance and adaptation of members of the genus Pseudoalteromonas, through the production of hydrolytic enzymes such as lipase, chitinase, agarase, amylase and protease, mean that they have an important role in their habitats (Ivanova et al., 2003). Members of the genus Pseudoalteromonas also produce many bioactive compounds and have important interactive roles with marine fauna and flora (Bowman, 2007; Thomas et al., 2008). At the time of writing, the genus Pseudoalteromonas comprises 34 recognized species and two subspecies (Euzéby, 1997). In the course of our screening programme for biopolymer-degrading bacteria from deep seawater, a novel strain, designated HJ51 ${ }^{\mathrm{T}}$, was isolated from the East Sea, near South Korea.

Seawater samples from the East Sea, $6 \mathrm{~km}$ from the coast $\left(38^{\circ} 21^{\prime} 25^{\prime \prime} \mathrm{N} 128^{\circ} 35^{\prime} 30^{\prime \prime} \mathrm{E}\right)$ and at depths of 200-500 m,

The GenBank/EMBL/DDBJ accession number for the $16 \mathrm{~S}$ rRNA gene sequence of strain $\mathrm{HJ}_{51}{ }^{\top}$ is $\mathrm{FJ} 754319$.

A supplementary table is available with the online version of this paper. were collected by the Deep Ocean Water Application Research Center from July 2005 to June 2006. Samples were stored at $4{ }^{\circ} \mathrm{C}$ in darkness for several months until required for bacterial isolation. For isolation of strain $\mathrm{HJ} 51^{\mathrm{T}}, 200 \mu \mathrm{l}$ seawater was serially diluted and spread on 1/10 marine agar 2216 (MA; Difco) and incubated at $25{ }^{\circ} \mathrm{C}$ for 7 days. Single colonies were purified by repeated streaking on MA. Strain $\mathrm{HJ} 51^{\mathrm{T}}$ was grown routinely in marine broth 2216 (MB; Difco) and YPS broth or on MA and YPS agar. YPS medium contained $\left(1^{-1}\right) 1 \mathrm{~g}$ yeast extract, $5 \mathrm{~g}$ peptone and $20 \mathrm{~g} \mathrm{NaCl}$ (15 g agar). Cultures were stored at $-80{ }^{\circ} \mathrm{C}$ in $\mathrm{MB}$ with $25 \%$ (v/v) glycerol. The reference strains Pseudoalteromonas mariniglutinosa DSM $15203^{\mathrm{T}}$ (Romanenko et al. 2003) and Pseudoalteromonas prydzensis DSM $14232^{\mathrm{T}}$ (Bowman, 1998) were obtained from the DSMZ (Braunschweig, Germany).

Morphology and cell size were determined by phasecontrast microscopy (80i; Nikon). Gram-staining was performed with BD Gram-stain kits according to the instructions of the manufacturer and the non-staining method as described by Buck (1982). Catalase activity was determined by bubble production in $3 \%(\mathrm{v} / \mathrm{v}) \mathrm{H}_{2} \mathrm{O}_{2}$ and oxidase activities were determined using oxidase reagent (bioMérieux), according to the manufacturer's instructions, after cultivation for 2 days. Hydrolysis of casein, starch, Tween 80 and agar was tested as described by Smibert \& Krieg (1994), using MA as the basal medium. 
Hydrolysis of chitin was determined on MA supplemented with $1.0 \%$ soluble chitin and detection of DNase was performed on DNase test agar (Difco) supplemented with $2.0 \% \mathrm{NaCl}$. Acid production from glucose, single-carbonsource assimilation and additional physiological characteristics were determined using the API 20NE, API ID32 GN and API ZYM galleries (bioMérieux), according to the manufacturer's instructions, except that cells were suspended in $2 \%(\mathrm{w} / \mathrm{v}) \mathrm{NaCl}$ solution. Growth at $0,4,10,15$, $20,25,30,35,37,40$ and $45{ }^{\circ} \mathrm{C}$, at $\mathrm{pH} 5.0-10.0$ (at intervals of $0.5 \mathrm{pH}$ unit) and with $0-14 \%(\mathrm{w} / \mathrm{v}) \mathrm{NaCl}$ was determined on YPS agar for 14 days at $25{ }^{\circ} \mathrm{C}$ and with $2 \% \mathrm{NaCl}$ unless otherwise stated.

Strain $\mathrm{HJ} 51^{\mathrm{T}}$ was shown to be Gram-negative with both tests. Cells were aerobic, motile rods $(0.4-0.6 \times 1.5-$ $3.5 \mu \mathrm{m}$ ), which were within the limits previously described for members of the genus Pseudoalteromonas. Colonies on MA after 3 days were smooth, slimy, non-pigmented, translucent and $4.0-6.0 \mathrm{~mm}$ in diameter. Strain $\mathrm{HJ} 51^{\mathrm{T}}$ was oxidase- and catalase-positive and grew with $1-13 \%(\mathrm{w} / \mathrm{v})$ $\mathrm{NaCl}$ (optimum 2\% $\mathrm{NaCl}$ ); no growth occurred without $\mathrm{NaCl}$. Strain $\mathrm{HJ} 51^{\mathrm{T}}$ grew at $4-40{ }^{\circ} \mathrm{C}$ (optimum $25-30{ }^{\circ} \mathrm{C}$ ); no growth occurred at $0{ }^{\circ} \mathrm{C}$ or $45{ }^{\circ} \mathrm{C}$. Strain $\mathrm{HJ} 51^{\mathrm{T}}$ grew at pH 5.5-9.5 (optimum 6.5-7.0). Strain $\mathrm{HJ} 51^{\mathrm{T}}$ could not only hydrolyse casein, DNA and starch, as can most of its close phylogenetic neighbours, but also it could weakly hydrolyse agar and chitin, which are rarely degraded by members of the genus Pseudoalteromonas, and aesculin and gelatin. Reduction of nitrates to nitrites and acidification of glucose by strain $\mathrm{HJ} 51^{\mathrm{T}}$ were observed. Strain $\mathrm{HJ} 51^{\mathrm{T}}$ was discriminated from its closest phylogenetic neighbours, P. mariniglutinosa DSM $15203^{\mathrm{T}}$ and P. prydzensis DSM $14232^{\mathrm{T}}$, by having positive reactions for assimilation of L-histidine, 3-hydroxybutyrate, acetate, D-mannose and trisodium citrate and production of $\alpha$-chymotrypsin, $\alpha$-fucosidase and urease (Table 1). Phenotypic comparison of strain $\mathrm{HJ}_{51}{ }^{\mathrm{T}}$ with other members of the genus Pseudoalteromonas is provided in Supplementary Table S1 (available in IJSEM Online).

For cellular fatty acid analysis, strain $\mathrm{HJ} 51^{\mathrm{T}}$ and the reference strains were cultivated for 3 days on MA. The fatty acids were saponified, methylated and extracted according to the protocol of the Sherlock Microbial Identification System (MIDI) and analysed by GC (6890; Hewlett Packard) using the Microbial Identification software (Sasser, 1990). Isoprenoid quinones were extracted with chloroform/methanol $(2: 1, \mathrm{v} / \mathrm{v})$, evaporated under vacuum conditions and re-extracted in $n$-hexane/water $(1: 1, \mathrm{v} / \mathrm{v})$. The crude quinone in $n$-hexane was purified using Sep-Pak Vac Cartridges Silica (Waters) and subsequently analysed by HPLC, as described by Hiraishi et al. (1996). For the measurement of the $G+C$ content of the chromosomal DNA, genomic DNA was extracted and enzymically degraded into nucleosides and the $\mathrm{G}+\mathrm{C}$ content was determined as described by Mesbah et al. (1989) using reversed-phase HPLC.
Table 1. Phenotypic characteristics of strain $\mathrm{HJ}_{51}{ }^{\top}$ and closely related type strains of species of the genus Pseudoalteromonas

Taxa: $1, \mathrm{HJ} 51^{\mathrm{T}} ; 2$, P. mariniglutinosa DSM $15203^{\mathrm{T}} ; 3$, P. prydzensis DSM $14232^{\mathrm{T}}$. All data were taken from this study except where indicated. All strains were positive for assimilation of L-arabinose, D-glucose, maltose, sucrose, propionate, $N$-acetylglucosamine, L-proline and L-serine, production of catalase, oxidase, alkaline phosphatase, esterase (C4), esterase lipase (C8), leucine arylamidase, valine arylamidase, trypsin, acid phosphatase, naphthol-AS-BI-phosphohydrolase, $N$-acetyl- $\beta$-glucosaminidase, $\alpha$-mannosidase, agarase (weakly), amylase, caseinase, chitinase (weakly) and DNase and hydrolysis of aesculin and gelatin. All strains were negative for Gramstaining, reduction of nitrates to nitrogen, assimilation of L-fucose, melibiose, D-ribose, inositol, D-sorbitol, caprate, citrate, itaconate, malonate, suberate, valerate, 3-hydroxybenzoate, 4-hydroxybenzoate, 5-ketogluconate, potassium gluconate, adipic acid and phenylacetic acid and production of indole, lipase (C14), cystine arylamidase, $\alpha$ galactosidase, $\beta$-galactosidase, $\beta$-glucuronidase and arginine dihydrolase. + , Positive; $\mathrm{w}$, weakly positive; - , negative.

\begin{tabular}{|c|c|c|c|}
\hline Characteristic & 1 & 2 & 3 \\
\hline Growth at $40{ }^{\circ} \mathrm{C}$ & + & - & - \\
\hline Reduction of nitrates to nitrites & + & - & - \\
\hline Acid production from glucose & + & - & + \\
\hline \multicolumn{4}{|l|}{ Production of: } \\
\hline$\alpha$-Chymotrypsin & + & - & - \\
\hline$\alpha$-Fucosidase & + & - & - \\
\hline$\alpha$-Glucosidase & $\mathrm{W}$ & - & $\mathrm{W}$ \\
\hline Urease & + & - & - \\
\hline \multicolumn{4}{|l|}{ Assimilation of: } \\
\hline Acetate & + & - & - \\
\hline L-Alanine & + & - & + \\
\hline Glycogen & $\mathrm{W}$ & - & + \\
\hline L-Histidine & + & - & - \\
\hline 3-Hydroxybutyrate & + & - & - \\
\hline 2-Ketogluconate & - & - & + \\
\hline DL-Lactate & - & + & - \\
\hline Malic acid & - & $\mathrm{w}$ & + \\
\hline Mannitol & - & + & - \\
\hline D-Mannose & + & - & - \\
\hline Rhamnose & - & + & - \\
\hline Salicin & - & + & - \\
\hline Trisodium citrate & + & - & - \\
\hline DNA G $+C$ content $(\mathrm{mol} \%)^{*}$ & 41.8 & 40.3 & $38-39$ \\
\hline
\end{tabular}

${ }^{*}$ Data for P. mariniglutinosa DSM $15203^{\mathrm{T}}$ and P. prydzensis DSM $14232^{\mathrm{T}}$ were taken from Romanenko et al., (2003) and Bowman (1998), respectively.

The cellular fatty acid contents of strain $\mathrm{HJ} 51^{\mathrm{T}}$ and the two reference strains are shown in Table 2. Strain $\mathrm{HJ}_{51}{ }^{\mathrm{T}}$ contained summed feature $4\left(\mathrm{C}_{16: 1} \omega 7 c\right.$ and/or iso- $\mathrm{C}_{15: 0} 2$ $\mathrm{OH} ; 30.66 \%), \mathrm{C}_{16: 0}(23.17 \%)$ and summed feature 7 $\left(\mathrm{C}_{18: 1} \omega 7 c, \mathrm{C}_{18: 1} \omega 9 t\right.$ and/or $\left.\mathrm{C}_{18: 1} \omega 12 t, 23.01 \%\right)$ as the major fatty acids and significant amounts of $\mathrm{C}_{12: 0} 3-\mathrm{OH}$ $(7.34 \%)$. This fatty acid composition was in accordance 
Table 2. Fatty acid contents of strain $\mathrm{HJ}_{51}{ }^{\top}$ and closely related type strains of species of the genus Pseudoalteromonas

Strains: $1, \mathrm{HJ} 51^{\mathrm{T}} ; 2$, P. mariniglutinosa DSM $15203^{\mathrm{T}} ; 3$, P. prydzensis DSM $14232^{\mathrm{T}}$. All data were taken from this study. Fatty acids comprising $<0.5 \%$ in all strains are not shown. - , Not detected/not reported; ECL, equivalent chain-length.

\begin{tabular}{|c|c|c|c|}
\hline Fatty acid (\%) & 1 & 2 & 3 \\
\hline \multicolumn{4}{|l|}{ Saturated } \\
\hline $\mathrm{C}_{12: 0}$ & 1.76 & 2.23 & 2.26 \\
\hline $\mathrm{C}_{14: 0}$ & 1.21 & 1.10 & 1.60 \\
\hline $\mathrm{C}_{15: 0}$ & - & 0.27 & 0.35 \\
\hline $\mathrm{C}_{16: 0}$ & 23.17 & 29.66 & 32.31 \\
\hline $\mathrm{C}_{17: 0}$ & 0.83 & 0.92 & 0.55 \\
\hline $\mathrm{C}_{18: 0}$ & 2.90 & 3.19 & 2.38 \\
\hline \multicolumn{4}{|l|}{ Unsaturated } \\
\hline $\mathrm{C}_{16: 1} \omega 9 c$ & 0.53 & 0.48 & 0.40 \\
\hline $\mathrm{C}_{17: 1} \omega 7 c$ & 1.23 & - & - \\
\hline $\mathrm{C}_{17: 1} \omega 8 c$ & - & 1.04 & 0.66 \\
\hline $\mathrm{C}_{18: 1} \omega 9 c$ & 1.42 & 1.26 & 1.07 \\
\hline $\mathrm{C}_{20: 1} \omega 9 t$ & 0.65 & 0.29 & - \\
\hline $\mathrm{C}_{20: 4} \omega 6,9,12,15 c$ & 0.84 & - & - \\
\hline \multicolumn{4}{|l|}{ Branched-chain } \\
\hline iso- $\mathrm{C}_{12: 0} 3-\mathrm{OH}$ & 0.71 & 0.31 & 0.53 \\
\hline iso- $\mathrm{C}_{16: 0}$ & 0.48 & - & 0.37 \\
\hline \multicolumn{4}{|l|}{ Hydroxy } \\
\hline $\mathrm{C}_{10: 0} 3-\mathrm{OH}$ & 0.56 & 0.48 & 0.43 \\
\hline $\mathrm{C}_{12: 0} 3-\mathrm{OH}$ & 7.34 & 7.87 & 8.41 \\
\hline $\mathrm{C}_{12: 1} 3-\mathrm{OH}$ & - & 0.26 & - \\
\hline $\mathrm{C}_{16: 0} 3-\mathrm{OH}$ & 0.52 & 0.47 & 0.57 \\
\hline \multicolumn{4}{|l|}{ Summed features ${ }^{*}$} \\
\hline 3 & 0.76 & 0.45 & 0.49 \\
\hline 4 & 30.66 & 32.32 & 33.30 \\
\hline 7 & 23.01 & 15.28 & 12.15 \\
\hline $\mathrm{C}_{19: 0}$ 10-methyl & - & 0.41 & 0.37 \\
\hline Unknown ECL 11.80 & 1.42 & 0.71 & 1.79 \\
\hline
\end{tabular}

*Summed features represent two or three fatty acids that cannot be separated by the Microbial Identification System. Summed feature 3 consisted of $\mathrm{C}_{14: 0} 3-\mathrm{OH}$ and/or iso- $\mathrm{C}_{16: 1}$ I. Summed feature 4 consisted of $\mathrm{C}_{16: 1} \omega 7 c$ and/or iso- $\mathrm{C}_{15: 0}$ 2-OH. Summed feature 7 consisted of one or more of $\mathrm{C}_{18: 1} \omega 7 c, \mathrm{C}_{18: 1} \omega 9 t$ and $\mathrm{C}_{18: 1} \omega 12 t$. The double bond position indicated by a capital letter is unknown.

with closely related members of the genus Pseudoalteromonas. However, the proportions of $\mathrm{C}_{16: 0}$ and summed feature 7 were different between strain $\mathrm{HJ} 51^{\mathrm{T}}$ and the reference strains. In addition, small amounts of $\mathrm{C}_{17: 1} \omega 7 c$ and $\mathrm{C}_{20: 4} \omega 6,9,12,15 c$ were found only in strain $\mathrm{HJ} 51^{\mathrm{T}}$. Strain $\mathrm{HJ} 51^{\mathrm{T}}$ contained ubiquinone- 8 as the major respiratory lipoquinone. The DNA $\mathrm{G}+\mathrm{C}$ content was $41.8 \mathrm{~mol} \%$.

For phylogenetic analysis, genomic DNA was extracted using a genomic DNA extraction kit (Solgent). The $16 \mathrm{~S}$ rRNA gene was amplified using the universal bacterial primer set $27 \mathrm{~F}$ and $1492 \mathrm{R}$ and the purified amplification products were sequenced by Solgent (Park et al., 2006). A full sequence (1506 bp) was obtained using SeqMan (DNASTAR) and compiled with 16S rRNA gene sequences of related taxa obtained from GenBank. Multiple alignment was performed using CLUSTAL_X (Thompson et al., 1997) and gaps were edited using BioEdit (Hall, 1999). Evolutionary distances were calculated using the Kimura two-parameter model (Kimura, 1980). Phylogenetic trees were constructed using neighbour joining (Saitou \& Nei, 1987) with MEGA3 (Kumar et al., 2004) and maximum likelihood (Felsenstein, 1981) with PHYLIP (Felsenstein, 1993). Bootstrap values were calculated using 1000 replications (Felsenstein, 1985).

Phylogenetic analysis of the $16 \mathrm{~S}$ rRNA gene sequence showed that strain $\mathrm{HJ} 51^{\mathrm{T}}$ was a member of the genus Pseudoalteromonas. The neighbour-joining and maximumlikelihood trees revealed that strain $\mathrm{HJ}_{51}{ }^{\mathrm{T}}$ clustered with Pseudoalteromonas lipolytica LMEB $39^{\mathrm{T}}$ (Xu et al., 2010), P. mariniglutinosa KMM $3635^{\mathrm{T}}$ (Romanenko et al., 2003) and P. prydzensis ACAM 620 (Bowman, 1998) (Fig. 1). Strain $\mathrm{HJ} 51^{\mathrm{T}}$ was most similar to P. lipolytica LMEB $39^{\mathrm{T}}(98.9 \%$ $16 \mathrm{~S}$ rRNA gene sequence similarity) and $P$. mariniglutinosa KMM $3635^{\mathrm{T}}(98.1 \%)$, and showed lower levels of similarity to $P$. prydzensis ACAM $620^{\mathrm{T}}(97.4 \%)$ and the other type strains included in the analysis (91.7-96.8\%).

DNA-DNA hybridization between strain $\mathrm{HJ} 51^{\mathrm{T}}$ and the reference strains was performed using photobiotin-labelled DNA probes and micro-dilution wells as described by Ezaki et al. (1989). Hybridization was performed with five replications for each sample, the highest and lowest values were excluded and the mean of the remaining three values was quoted as the DNA-DNA relatedness value.

Currently in bacterial systematics, species are defined if they show $<70 \%$ DNA-DNA relatedness (Wayne et al., 1987 ) and organisms that have $<97 \% 16 \mathrm{~S}$ rRNA gene sequence similarity will not show $>60 \%$ DNA-DNA relatedness, regardless of the hybridization method employed (Stackebrandt \& Goebel, 1994). However, with the genera Pseudoalteromonas and Amycolatopsis, the cutoff value for DNA-DNA relatedness should be $99.0 \%$ (Romanenko et al., 2003; Wink et al., 2003). DNA-DNA relatedness values between strain $\mathrm{HJ} 51^{\mathrm{T}}$ and $P$. mariniglutinosa DSM $15203^{\mathrm{T}}$ and P. prydzensis DSM $14232^{\mathrm{T}}$, which showed $>97 \% 16 \mathrm{~S}$ rRNA gene similarity, were $7.2 \%$ and $12.9 \%$, respectively, which clearly indicated that strain $\mathrm{HJ} 51^{\mathrm{T}}$ represented a novel species.

Therefore, on the basis of phenotypic, chemotaxonomic and genotypic data, strain $\mathrm{HJ} 51^{\mathrm{T}}$ should be classified as representing a novel species of the genus Pseudoalteromonas, for which the name Pseudoalteromonas donghaensis sp. nov. is proposed.

\section{Description of Pseudoalteromonas donghaensis sp. nov.}

Pseudoalteromonas donghaensis (dong.ha.en'sis. N.L. fem. adj. donghaensis of or belonging to Donghae, the Korean name for the East Sea, from which the type strain was isolated). 


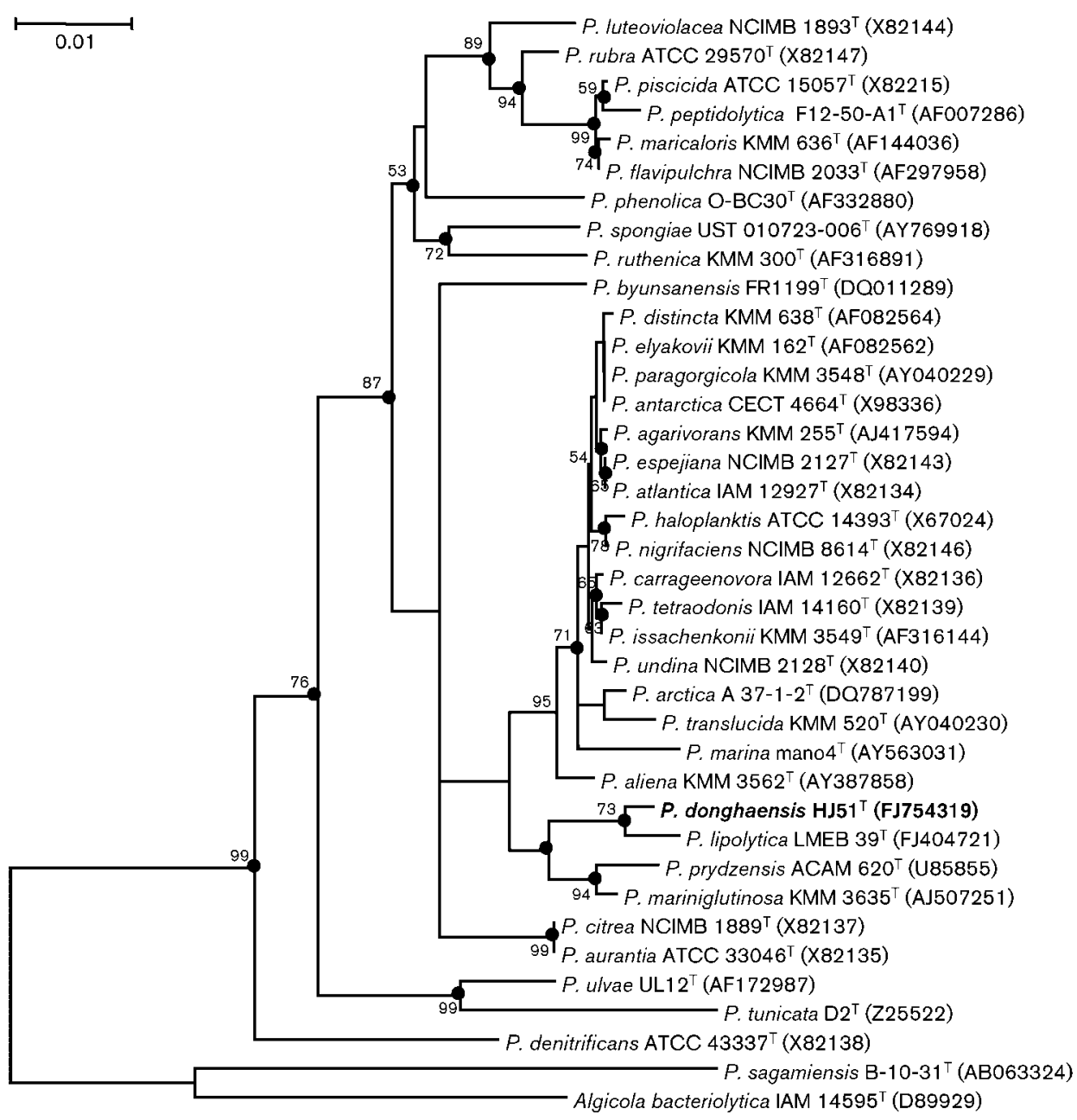

Fig. 1. Neighbour-joining tree based on $16 \mathrm{~S}$ rRNA gene sequences showing the phylogenetic relationship of strain $\mathrm{HJ} 51^{\top}$ within the genus Pseudoalteromonas. Bootstrap values ( $>50 \%$ ) based on 1000 replications are shown at branch nodes. Filled circles indicate that the corresponding nodes were also recovered with the maximum-likelihood method. Algicola bacteriolytica IAM $14595^{\top}$ was used as an outgroup. Bar, 0.01 substitutions per nucleotide position.

Cells are Gram-negative, motile, aerobic rods, $0.4-0.6 \mu \mathrm{m}$ wide and 1.5-3.5 $\mu \mathrm{m}$ long. Colonies are smooth, mucoidal, translucent and non-pigmented, $4.0-6.0 \mathrm{~mm}$ in diameter, on MA. Oxidase- and catalase-positive. $\mathrm{NaCl}$ is essential for growth; growth is observed with $1-13 \%(\mathrm{w} / \mathrm{v}) \mathrm{NaCl}$ (optimum $2-3 \% \mathrm{NaCl}$ ). Growth occurs slowly at $4{ }^{\circ} \mathrm{C}$, but not at $45{ }^{\circ} \mathrm{C}$ (optimum $25-30{ }^{\circ} \mathrm{C}$ ). Growth occurs at pH 5.5-9.5 (optimum pH 6.5-7.0). Reduces nitrates to nitrites, but not to nitrogen. Produces acid from glucose. Does not produce indole. Hydrolyses aesculin, casein, DNA, gelatin and starch and weakly hydrolyses chitin and agar. Produces alkaline phosphatase, urease, protease, esterase (C4), esterase lipase (C8), leucine arylamidase, valine arylamidase, trypsin, $\alpha$-chymotrypsin, acid phosphatase, naphthol-AS-BI-phosphohydrolase, $\alpha$-fucosidase, $\alpha$-glucosidase (weakly), $N$-acetyl- $\beta$-glucosaminidase and $\alpha$ mannosidase, but not lipase (C14), cystine arylamidase, $\alpha$-galactosidase, $\beta$-galactosidase, $\beta$-glucuronidase or arginine dihydrolase. Utilizes L-arabinose, D-glucose, maltose, D-mannose, sucrose, L-alanine, L-histidine, L-proline, L-serine, acetate, trisodium citrate, propionate, 3-hydroxybutyrate, $N$-acetylglucosamine and glycogen as sole carbon sources, but not L-fucose, melibiose, rhamnose, D-ribose, salicin, inositol, mannitol, D-sorbitol, caprate, citrate, itaconate, DL-lactate, malonate, suberate, valerate, 2-ketogluconate, 3-hydroxybenzoate, 4-hydroxybenzoate, 5-ketogluconate, potassium gluconate, adipic acid, malic acid or phenylacetic acid. The predominant ubiquinone is Q- 8 . The major fatty acids are summed feature $4\left(\mathrm{C}_{16: 1} \omega 7 c\right.$ and/or iso- $\left.\mathrm{C}_{15: 0} 2-\mathrm{OH}\right), \mathrm{C}_{16: 0}$ and summed feature $7\left(\mathrm{C}_{18: 1} \omega 7 c\right.$, $\mathrm{C}_{18: 1} \omega 9 t$ and/or $\left.\mathrm{C}_{18: 1} \omega 12 t\right)$.

The type strain, HJ51 ${ }^{\mathrm{T}}\left(=\right.$ KCTC $\left.22219^{\mathrm{T}}=\mathrm{LMG} 24469^{\mathrm{T}}\right)$, was isolated from seawater (depth $200-500 \mathrm{~m}$ ) of the East Sea, near South Korea. The DNA G $+\mathrm{C}$ content of the type strain is $41.8 \mathrm{~mol} \%$. 


\section{Acknowledgements}

This work was supported by a grant from the Korean Ministry of Education, Science and Technology (The Regional Core Research Program/Chungbuk BIT Research-Oriented University Consortium).

\section{References}

Baumann, L., Baumann, P., Mandel, M. \& Allen, R. D. (1972), Taxonomy of aerobic marine eubacteria. J Bacteriol 110, 402-429.

Bowman, J. P. (1998). Pseudoalteromonas prydzensis sp. nov., a psychrotrophic, halotolerant bacterium from Antarctic sea ice. Int $J$ Syst Bacteriol 48, 1037-1041.

Bowman, J. P. (2007). Bioactive compound synthetic capacity and ecological significance of marine bacterial genus Pseudoalteromonas. Mar Drugs 5, 220-241.

Buck, J. D. (1982). Nonstaining $(\mathrm{KOH})$ method for determination of gram reactions of marine bacteria. Appl Environ Microbiol 44, 992-993.

Euzéby, J. P. (1997). List of bacterial names with standing in nomenclature: a folder available on the Internet. Int J Syst Bacteriol 47, 590-592.

Ezaki, T., Hashimoto, Y. \& Yabuuchi, E. (1989). Fluorometric deoxyribonucleic acid-deoxyribonucleic acid hybridization in microdilution wells as an alternative to membrane filter hybridization in which radioisotopes are used to determine genetic relatedness among bacterial strains. Int J Syst Bacteriol 39, 224-229.

Felsenstein, J. (1981). Evolutionary trees from DNA sequences: a maximum likelihood approach. J Mol Evol 17, 368-376.

Felsenstein, J. (1985). Confidence limit on phylogenies: an approach using the bootstrap. Evolution 39, 783-791.

Felsenstein, J. (1993). PHYLIP (phylogeny inference package), version 3.5c. Distributed by the author. Department of Genome Sciences, University of Washington, Seattle, USA.

Gauthier, G. \& Breittmayer, V. A. (1979). A new antibiotic-producing bacterium from seawater: Alteromonas aurantia sp. nov. Int J Syst Bacteriol 29, 366-372.

Gauthier, G., Gauthier, M. \& Christen, R. (1995). Phylogenetic analysis of the genera Alteromonas, Shewanella, and Moritella using genes coding for small-subunit rRNA sequences and division of the genus Alteromonas into two genera, Alteromonas (emended) and Pseudoalteromonas gen. nov., and proposal of twelve new species combinations. Int J Syst Bacteriol 45, 755-761.

Hall, T. A. (1999). BioEdit: a user-friendly biological sequence alignment editor and analysis program for Windows 95/98/NT. Nucleic Acids Symp Ser 41, 95-98.

Hiraishi, A., Ueda, Y., Ishihara, J. \& Mori, T. (1996). Comparative lipoquinone analysis of influent sewage and activated sludge by highperformance liquid chromatography and photodiode array detection. J Gen Appl Microbiol 42, 457-469.

Ivanova, E. P., Sawabe, T., Alexeeva, Y. V., Lysenko, A. M., Gorshkova, N. M., Hayashi, K., Zukova, N. V., Christen, R. \& Mikhailov, V. V. (2002a). Pseudoalteromonas issachenkonii sp. nov., a bacterium that degrades the thallus of the brown alga Fucus evanescens. Int J Syst Evol Microbiol 52, 229-234.

Ivanova, E. P., Sawabe, T., Lysenko, A. M., Gorshkova, N. M., Svetashev, V. I., Nicolau, D. V., Yumoto, N., Taguchi, T., Yoshikawa, S. \& other authors (2002b). Pseudoalteromonas ruthenica sp. nov., isolated from marine invertebrates. Int J Syst Evol Microbiol 52, 235-240.

Ivanova, E. P., Bakunina, I. Y., Nedashkovskaya, O. I., Gorshkova, N. M., Alexeeva, Y. V., Xelepuga, E. A., Zvaygintseva, T. N., Nicolau, D. V. \& Mikhailov, V. V. (2003). Ecophysiological variabilities in ectohydrolytic enzyme activities of some Pseudoalteromonas species, P. citrea, P. issachenkonii, and P. nigrifaciens. Curr Microbiol 46, 6-10.

Ivanova, E. P., Gorshkova, N. M., Zhukova, N. V., Lysenko, A. M., Zelepuga, E. A., Prokof'eva, N. G., Mikhailov, V. V., Nicolau, D. V. \& Christen, R. (2004). Characterization of Pseudoalteromonas distinctalike sea-water isolates and description of Pseudoalteromonas aliena sp. nov. Int J Syst Evol Microbiol 54, 1431-1437.

Kimura, M. (1980). A simple method for estimating evolutionary rates of base substitutions through comparative studies of nucleotide sequences. J Mol Evol 16, 111-120.

Kumar, S., Tamura, K. \& Nei, M. (2004). MEGA3: Integrated software for molecular evolutionary genetics analysis and sequence alignment. Brief Bioinform 5, 150-163.

Mesbah, M., Premachandran, U. \& Whitman, W. B. (1989). Precise measurement of the $\mathrm{G}+\mathrm{C}$ content of deoxyribonucleic acid by highperformance liquid chromatography. Int J Syst Bacteriol 39, 159-167.

Park, Y.-D., Baik, K. S., Yi, H., Bae, K. S. \& Chun, J. (2005). Pseudoalteromonas byunsanensis sp. nov., isolated from tidal flat sediment in Korea. Int J Syst Evol Microbiol 55, 2519-2523.

Park, J. W., Oh, Y. S., Lim, J. Y. \& Roh, D. H. (2006). Isolation and characterization of cold-adapted strains producing $\beta$-galactosidase. J Microbiol 44, 396-402.

Romanenko, L. A., Zhukova, N. V., Lysenko, A. M., Mikhailov, V. V. \& Stackebrandt, E. (2003). Assignment of 'Alteromonas marinoglutinosa' NCIMB 1770 to Pseudoalteromonas mariniglutinosa sp. nov., nom. rev., comb. nov. Int J Syst Evol Microbiol 53, 1105-1109.

Saitou, N. \& Nei, M. (1987). The neighbor-joining method: a new method for reconstructing phylogenetic trees. Mol Biol Evol 4, 406425.

Sasser, M. (1990). Identification of bacteria by gas chromatography of cellular fatty acids, MIDI Technical Note 101. Newark, DE: MIDI Inc.

Smibert, R. M. \& Krieg, N. R. (1994). Phenotypic characterization. In Methods for General and Molecular Bacteriology, pp. 607-655. Edited by P. Gerhardt, R. G. E. Murray, W. A. Wood \& N. R. Krieg. Washington, DC: American Society for Microbiology.

Stackebrandt, E. \& Goebel, B. M. (1994). Taxonomic note: a place for DNA-DNA reassociation and $16 \mathrm{~S}$ rRNA sequence analysis in the present species definition in bacteriology. Int J Syst Bacteriol 44, 846-849.

Thomas, T., Evans, F. F., Schleheck, D., Mai-Prochnow, A., Burke, C., Penesyan, A., Dalisay, D. S., Stelzer-Braid, S., Saunders, N. \& other authors (2008). Analysis of the Pseudoalteromonas tunicata genome reveals properties of a surface-associated life style in the marine environment. PLoS ONE 3, e3252.

Thompson, J. D., Gibson, T. J., Plewniak, F., Jeanmougin, F. \& Higgins, D. G. (1997). The CLUSTAL_X windows interface: flexible strategies for multiple sequence alignment aided by quality analysis tools. Nucleic Acids Res 25, 4876-4882.

Wayne, L. G., Brenner, D. J., Colwell, R. R., Grimont, P. A. D., Kandler, O., Krichevsky, M. I., Moore, L. H., Moore, W. E. C., Murray, R. G. E. \& other authors (1987). International Committee on Systematic Bacteriology. Report of the ad hoc committee on reconciliation of approaches to bacterial systematics. Int J Syst Bacteriol 37, 463-464.

Wink, J. M., Kroppenstedt, R. M., Ganguli, B. N., Nadkarni, S. R., Schumann, P., Seibert, G. \& Stackebrandt, E. (2003). Three new antibiotic producing species of the genus Amycolatopsis, Amycolatopsis balhimycina sp. nov., A. tolypomycina sp. nov., A. vancoresmycina sp. nov., and description of Amycolatopsis keratiniphila subsp. keratiniphila subsp. nov. and A. keratiniphila subsp. nogabecina subsp. nov. Syst Appl Microbiol 26, 38-46.

Xu, X.-W., Wu, Y.-H., Wang, C.-S., Gao, X. H., Wang, X.-G. \& Wu, M. (2010). Pseudoalteromonas lipolytica sp. nov., isolated from the Yangtze River estuary. Int J Syst Evol Microbiol 60, 2176-2181. 